\title{
Fuzzy Mathematical Approach to Analyze the Problems Faced By Turmeric Cultivators at the Time of Marketing
}

\author{
S. Narayanamoorthy'1, P. Shanmugam², K. Maheswari ${ }^{3}$ and S. Kalaiselvan ${ }^{3}$ \\ 'Department of Applied Mathematics, Bharathiar University, Coimbatore-641 046, India; snm_phd@yahoo.co.in \\ ²Department of Economics, Bharathiar University, Coimbatore-641 046, India; bushanmugam@gmail.com \\ ${ }^{3}$ Department of Social Work, Bharathidasan University Constituent College, Perambalur, Tamilnadu, India; \\ kalaiharitha@gmail.com, maheshranjith06@yahoo.co.in
}

\begin{abstract}
In this research paper, the authors attempt to find out the problems faced by the turmeric cultivators at the time of marketing in Tamil Nadu using Induced Fuzzy Cognitive Maps (IFCM's) Technique.
\end{abstract}

\section{Introduction}

Turmeric is a farm product that has more applications. The country consumes most (80\%) of its turmeric production and it exports the surplus. The findings of the study would help us to understand, the problems faced by the turmeric cultivators at the time of marketing in Erode District. The erode turmeric market is the leading turmeric market in south India. This study is based on the primary data. The required data were collected from the turmeric cultivators in and around Erode District of Tamil Nadu.

SenthilKumar ${ }^{4}$ has revealed that illiterate agriculturist have produced maximum quantity of spices (turmeric and chilly) than the educated respondents and the respondents who have allocated above five acres of land for cultivation of spices (turmeric and chilly) have produced maximum quantity of turmeric. The spices cultivators are facing several problems like bad weather, delayed rainfall, lack of technology, storage problem, influence of private vendors and intermediaries, forced sales for agriculture operation etc Turmeric prices also came under pressure due to sluggish demand from bulk buyers. In 1986 Kosko $^{1}$ introduced fuzzy cognitive maps and its properties. In 2000 Kandasamy $^{6}$ published a paper about FCM. Hence we have taken fuzzy to analyze the problem faced by turmeric cultivators at the time of marketing in Tamil Nadu.

\section{Methodology}

Here, we adapt Induced Fuzzy Cognitive Maps (IFCMs) to the problems faced by Turmeric Cultivators. The basic definitions of FCMs and its properties please refer Kasko ${ }^{1}$. The algorithm of Induced FCMs Please refer?

The seven major concepts relating to the turmeric cultivators as $\mathrm{A}_{1}$ - Lack of awareness about market information, $\mathrm{A}_{2}$ - Price fluctuation/Low price, $\mathrm{A}_{3}$ - High commission charges, $\mathrm{A}_{4}$ - Forced Sales, $\mathrm{A}_{5}$ - High cost of transport, $A_{6}$ - High cost of storage, $A_{7}$ - Delay in payment:

The related matrix $P$ is given by the expert is:

\begin{tabular}{|c|c|c|c|c|c|c|c|c|}
\hline & & $\mathrm{A}_{1}$ & $\mathrm{~A}_{2}$ & $\mathrm{~A}_{3}$ & $\mathrm{~A}_{4}$ & $\mathrm{~A}_{5}$ & $\mathrm{~A}_{6}$ & $\mathrm{~A}_{7}$ \\
\hline & $\mathrm{A}_{1}$ & 0 & 1 & 0 & 1 & 0 & 0 & \\
\hline & $\mathrm{A}_{2}$ & 0 & 0 & 0 & 0 & 1 & 1 & \\
\hline & $\mathrm{A}_{3}$ & 0 & 0 & 0 & 1 & 0 & 1 & \\
\hline$P$ & $\mathrm{~A}_{4}$ & 1 & 1 & 1 & 0 & 1 & 0 & \\
\hline & $\mathrm{A}_{5}$ & 0 & 0 & 0 & 0 & 0 & 1 & \\
\hline & $\mathrm{A}_{6}$ & 1 & 0 & 0 & 1 & 0 & 0 & 0 \\
\hline & $\mathrm{A}_{7}$ & 1 & 0 & 1 & 0 & 0 & 0 & \\
\hline
\end{tabular}


Now using the matrix $\mathrm{P}$ we determined the problems. Let us start Lack of awareness about market information is taken as the ON state and all the other nodes are in the OFF state.

(i.e) $\mathrm{R}_{1}=\left(\begin{array}{lllllll}1 & 0 & 0 & 0 & 0 & 0 & 0\end{array}\right)$

Product of $\mathrm{R}_{1}$ and $\mathrm{P}$ is calculated.

$$
\begin{aligned}
& \mathrm{R}_{1} \mathrm{P}=\left(\begin{array}{lllllll}
0 & 1 & 0 & 1 & 0 & 0 & 0
\end{array}\right) \hookrightarrow\left(\begin{array}{lllllll}
1 & 1 & 0 & 1 & 0 & 0 & 0
\end{array}\right)=\mathrm{R}_{1}{ }^{1} \\
& \mathrm{R}_{1}{ }_{1} \mathrm{X} P \sim\left(\begin{array}{lllllll}
1 & 0 & 0 & 0 & 0 & 0 & 0
\end{array}\right) \times \mathrm{P} \rightarrow\left(\begin{array}{lllllll}
0 & 1 & 0 & 1 & 0 & 0 & 0
\end{array}\right)
\end{aligned}
$$

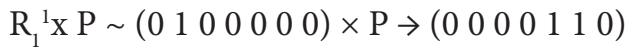

$$
\begin{aligned}
& \mathrm{R}_{1}{ }^{1} \mathrm{x} \mathrm{P} \sim\left(\begin{array}{lllllll}
0 & 0 & 0 & 1 & 0 & 0 & 0
\end{array}\right) \times \mathrm{P} \rightarrow\left(\begin{array}{lllllll}
1 & 1 & 1 & 0 & 1 & 0 & 1
\end{array}\right)
\end{aligned}
$$

Therefore $\mathrm{R}_{2}=\left(\begin{array}{lllllll}1 & 1 & 1 & 0 & 1 & 0 & 1\end{array}\right)$

$$
\begin{aligned}
& \mathrm{R}_{2} \mathrm{x} \mathrm{P} \hookrightarrow\left(\begin{array}{lllllll}
1 & 1 & 1 & 1 & 1 & 1 & 1
\end{array}\right) \\
& \mathrm{R}_{2}{ }^{1}=\left(\begin{array}{lllllll}
1 & 1 & 1 & 1 & 0 & 1 & 1
\end{array}\right) \\
& \mathrm{R}_{2}{ }^{1} \mathrm{x} P \sim\left(\begin{array}{lllllll}
1 & 0 & 0 & 0 & 0 & 0 & 0
\end{array}\right) \times \mathrm{P} \rightarrow\left(\begin{array}{lllllll}
0 & 1 & 0 & 1 & 0 & 0 & 0
\end{array}\right)
\end{aligned}
$$

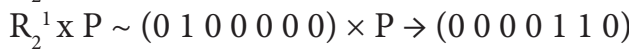

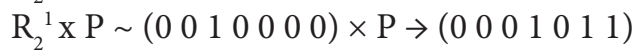

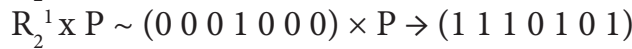

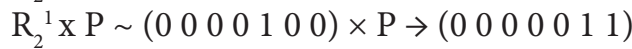

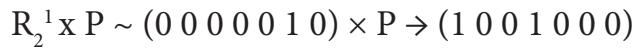

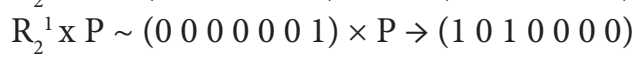

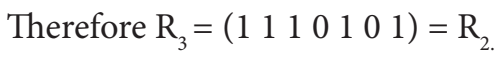
The fixed point is $R_{3}=\left(\begin{array}{lllllll}1 & 1 & 1 & 0 & 1 & 0 & 1\end{array}\right)$.

Likewise any number of state vectors to be considered as $\mathrm{ON}$ state.

When the same threshold value occurs twice, the value is considered as the fixed point. The iteration gets terminated and the calculation gets terminated.

\section{Conclusion}

- From the expert opinion, we found that when lack of awareness is taken as the $\mathrm{ON}$ state, the resultant vector is $\left(\begin{array}{lllllll}1 & 1 & 1 & 0 & 1 & 0 & 1\end{array}\right)$.
- It is clearly noted that from IFCMs the 'Delay in Payment' is the major problem faced by the turmeric cultivators.

- We found that the farmers were not having enough sources to know the market information about the price of turmeric.

- Finally it is suggested that the government has to take necessary steps in fixing the price by the commissions in favour of cultivators and timely payment to the cultivators will promote the turmeric production to a larger extent.

\section{References}

1. Kosko B. Fuzzy Cognitive Maps. Int J Man Mach Stud. 1986; 24:65-75.

2. Balasangu K, Thirusangu K, Dare RV. IFAM model approach on the impact of pesticides on agricultural labourers. Indian J Sci Technol. 2011; 4 (2):151-4.

3. Juliano BA, Bandler W. Tracing Chains-of-Thought: Fuzzy Methods in Cognitive Diagnosis. Heidelberg; PhysicaVerlag; 1996 Apr.

4. Senthilkumar C. A Study on Spices Production and Marketing in Erode District. Namex International Journal of Management Research. 2011 Dec; 1(1):12-7.

5. Thirusangu K, Elumalai P, Praveenprakash A. A new bidirectional associative Fuzzy Cognitive Dynamical system. Indian J Sci Technol. 2012; 5 (3):2333-40.

6. Kandasamy VWB, Sultana Y. Knowledge Processing using Fuzzy Relational Maps. Ultra Sci. 2000; 12:242-5.

7. Narayanamoorthy S, Kalaiselvan S. Adaptation of Induced Fuzzy Cognitive Maps to the Problems Faced by the Power Loom Workers. IJISA. 2012; 4(9):75-80. 